\title{
Genetics of seed quality attributes in Brassica napus L.
}

\author{
Muhammad Ali ${ }^{1 *}$, Raziuddin ${ }^{1}$, Iftikhar Hussain Khalil ${ }^{1}$, Ibni Amin \\ Khalil ${ }^{1}$, Anwar-ul-Haq ${ }^{1}$, Rafiullah Khan ${ }^{1}$, Ghulamullah ${ }^{1}$, Monsif Ur \\ Rehman $^{1}$ and Sanaullah Khan ${ }^{2}$
}

1. Department of Plant Breeding and Genetic, Faculty of Crop Production, The University of Agriculture, PeshawarPakistan.

2. School of Chemistry and Molecular Biosciences, The University of Queensland St Lucia Brisbane-Australia

*Corresponding author's email: alipbg@yahoo.com

Citation

Muhammad Ali, Raziuddin, Iftikhar Hussain Khalil, Ibni Amin Khalil, Anwar-ul-Haq, Rafiullah Khan,Ghulamullah, Monsif Ur Rehman and Sanaullah Khan. Genetics of seed quality attributes in Brassica napus L. Pure and Applied Biology. Vol. 5, Issue 4, pp1230-1244. http://dx.doi.org/10.19045/bspab.2016.50148

Received: 29/07/2016 $\quad$ Revised: 07/10/2016 $\quad$ Accepted: 15/10/2016 $\quad$ Online First: 09/11/2016

\section{Abstract}

A diallel analysis study for estimating the pattern of inheritance and heritability of oil content and quality attributes in Rapeseed (Brassica napus L.) was carried out at The department of Plant Breeding and Genetics, The University of Agriculture, Peshawar during crop season 2011-2012. Four diverse parents viz. G2, G4, G6 and G9 of Brassica napus L were used in a full diallel fashion during the $1^{\text {st }}$ year of experiment (Crop season 2010-2011). All the parents along with their $F_{1}$ hybrids were evaluated in field condition in the $2^{\text {nd }}$ year of experiment (Crop season 2011-2012) in randomized complete block design. Differences among these lines for Oil content, Protein content, Glucosinolate content, Erucic acid and Linolenic acid were found highly significant $(\mathrm{P} \leq 0.01)$, except Oleic acid for which non-significant differences were observed, so oleic acid was excluded from diallel analysis. Additive-dominance model was found fully adequate for Oil and Protein content, whereas it was partially adequate for the remaining traits under study. After diallel analysis results, highly significant additive (a) and non-additive (b) variances for characters such as Oil content, Protein content, Glucosinolate content and Erucic acid, while for Linolenic acid non-significant additive variance was observed. Estimation of genetic parameters showed higher magnitude and significance of non-additive component for all the seed quality traits except erucic acid, for which additive component was higher in magnitude. Graphical analysis showed overdominance for all of the parameters except erucic acid for which partial dominance was observed. Average degree of dominance value for Oil content (1.344), Protein content (1.636), Glucosinolate content (1.145) and Linolenic acid (4.156) also showed the importance of overdominance gene action responsible for all these studied seed quality traits, as it was greater than one, while for Erucic acid (0.803) it was lower the one showing partial dominance. For all the studied parameters, high broad sense heritability (0.70-0.96) and low narrow sense heritability (0.05-0.683) was estimated, showing the low role and magnitude of additive gene action and suggests selection for these traits in the later segregating generation/s.

Keywords: Diallel analysis; Seed quality traits; Erucic acid

\section{Introduction}

Oilseed crops are mainly cultivated for its oil content present in its seeds. Only 1-2\% oil content is found in small grains such as wheat, while a range of $20 \%$ (e.g. in soybeans) to more than $40 \%$ in oilseeds 
crops such as sunflowers and canola [1]. Rapeseed is grown for animal feed, vegetable oil and green diesel [2], but the production and use of green diesel in Pakistan is fiction of today and fact of tomorrow. Other products such as lubricants, hydraulic oils, detergents, soaps and recyclable plastics also depend on rapeseed [3]. Rapeseed residue known as meal, having $38-44 \%$ protein is a useful animal feed and also fertilizer for many crops [4]. Great importance of rapeseed is related to its seed oil content. In west oil of Brassica napus is given great importance for green diesel production, because compared to other oil crops it produces high oil content per unit area.

Canola, a Canadian invention is simply a desired variety of rapeseed (Brassica napus L.) with two distinct improved nutritional qualities i.e. less than $2 \%$ erucic acid in the oil and less than $30 \mu \mathrm{mol} / \mathrm{g}$ glucosinolate content in oilseeds cake. It is amongst the major global sources of edible seed oils along with sunflower, soybean, peanut and cotton. It (B. napus L.) belongs to the family Cruciferae (Brassicaceae), comprising of about 350 genera and 3000 species, including some important species such as $B$. campestris, $B$. napus, $B$. oleracea and $B$. juncea. Brassica napus origin in probably in the Mediterranean region and resulted from natural hybridization between $B$. oleracea and $B$. campestris. Canola varieties could also belong to $B$. napus, $B$. juncea or B. rapa.

Globally Canada is holding the top position of producing canola. Canada produces more than 13 million tons of canola each year. Half of this quantity is exported to various countries, amongst which United States, Japan and Mexico are on the top position. Through intensive and extensive agriculture changes could be made either to increase the yield potential of genetically manipulated cultivars of oilseeds crops or to change the production technology in order to harvest better yield. In order to consider the edible oil needs in the country and maladies in production, genetic manipulation requires breeding skills and devoted work. Successful improvement can only be made by manipulation of genetic structure of a crop/plant and creating genetic variation. According to Wang [5] one percent increase in oil content of B. napus can be obtained by about 2.3-2.5\% increase in seed production. To date most work on genetic analysis in $B$. napus has been carried out on erucic acid and glucosinolate content, along with protein content, due to their significant role in oil quality.

\section{Materials and methods}

Using full diallel fashion, the four genotypes of Brassica napus (G2, G4, G6 and G9) were crossed during growing season 20102011 at experimental farm of Department of Plant Breeding and Genetics. For this 20-25 flowers at bud stage of each genotype were chosen for emasculation, hand pollinated by shedding pollens with the desired male parent. The artificial cross pollinated buds were covered with butter paper bags from emasculation till pod formation time, in order to protect it from bees or any other causal agent of cross or self-pollination. In order to get sufficient amount of seeds, a minimum of 20 stigmas were artificially pollinated for each cross. Separate harvesting and threshing was conducted for each cross seeds at proper maturity. In the next year (cropping season 2011-2012), an $\mathrm{RCB}$ design with three replications was used for field evaluation of all parents $(\mathrm{G} 2, \mathrm{G} 4$, G6, G9) along with all single cross $F_{1}$ hybrids. Each genotype/cross and parents was sown in four rows of $5 \mathrm{~m}$ length with $30 \mathrm{~cm}$ row to row spacing. To reduce experimental error and obtained valid and conclusive results, regarding oil content (\%), protein content $(\%)$, glucosinolate content $\left(\mu \mathrm{mol} \mathrm{g}^{-1}\right)$, erucic acid $(\%)$, linolenic acid 
(\%) and oleic acid (\%) cultural practices were performed uniformly for all genotypes.

Using Near Infrared Reflectance Spectroscopy, NIRS [6] at Nuclear Institute for Food and Agriculture (NIFA) Peshawar, all the said seed quality traits were measured. A seed sample of $3 \mathrm{~g}$ was drawn from selected plants of each genotype replication $^{-1}$.

Additive-dominance model of Hayaman [7, 8 ] is mostly used method to evaluate the genetic basis of variation in $F_{1}$ and $F_{2}$ (early generations), along with magnitude and nature of genetic behavior. According to this technique total sum of square is partioned into components such as 'a', 'b', 'c' and 'd' (additive, dominance/non-additive, maternal and non-maternal reciprocal differences respectively). Further division of ' $b$ ' component is represented by $b_{1}, b_{2}$ and $b_{3}$ components of dominance. Significance of ' $a$ ' and ' $b$ ' component means the control of the concerned trait by additive effects of gene and dominance effects of gene respectively. Significance of $b_{1}$ shows directional dominance, $b_{2}$ shows asymmetrical gene distribution and $b_{3}$ shows specific effects of genes, while maternal effect is represented by ' $c$ ' and non-maternal reciprocal differences are represented by ' $\mathrm{d}$ '. Using $\mathrm{Vr}$ (variance) and $\mathrm{Wr}$ (covariance) for graphical analysis approach is valid only, when ' $b$ ' component is significant.

Testing adequacy of the additivedominance model

Two tests are conducted for the recorded data on studied parameters in order to identify adequacy of the additive-dominance model. These tests were $\mathrm{t}^{2}$ test for the uniformity of $\mathrm{Wr}$ and $\mathrm{Vr}$ and analysis of regression coefficient. For the completion of assumptions of diallel analysis, the result obtained from the $\mathrm{t}^{2}$ for the uniformity of $\mathrm{Wr}$ and $\mathrm{Vr}$ should be constant over arrays, while the analysis of regression coefficient following Mather and Jinks [9] for all traits in the present study should be different significantly from zero, but not from unity.

\section{Genetic parameters}

The following genetic parameters were computed

\begin{tabular}{|l|}
\hline Additive variance $=\mathrm{D}$ \\
\hline Estimate of dominance $=\mathrm{H} 1$, \\
\hline Dominance $\times$ dominance interaction $=\mathrm{H} 2$, \\
\hline Average degree of dominance $=(\mathrm{H} 1 / \mathrm{D}) 1 / 2$, \\
\hline Proportion of genes with positive and negative effects in the parents $=\mathrm{H} 2 / 4 \mathrm{H} 1$, \\
\hline Over all dominance effect due to heterozygous loci $=\mathrm{h} 2$ \\
\hline Dominant to recessive alleles frequency in parents $=\mathrm{F}$ \\
\hline Dominant to recessive genes ratio in parents $\left.=(4 \mathrm{DH} 1) 1 / 2+\mathrm{F} /(4 \mathrm{DH} 1) 1 / 2 \_\mathrm{F}\right)$, \\
\hline Environmental effect $=\mathrm{E}$, \\
\hline Broad sense heritability $=\mathrm{h}^{2} \mathrm{BS}$. \\
\hline Narrow sense heritability $=\mathrm{h}^{2} \mathrm{NS}$. \\
\hline
\end{tabular}

\section{Results and discussion}

In the present study, data on oil content (\%), protein content $(\%)$, glucosinolate content $\left(\mu \mathrm{mol} \mathrm{g} \mathrm{g}^{-1}\right)$, erucic acid $(\%)$, linolenic acid $(\%)$ and oleic acid (\%) were analyzed in two steps. First analysis of variance (ANOVA) following Steel and Torrie [10] was conducted for null hypothesis of equality of means. For all the studied characters highly significant differences $(\mathrm{P} \leq 0.01)$ were observed except oleic acid (\%) for which non-significant differences were observed, so oleic acid was excluded from diallel analysis (Table 1). Then in the second step 
diallel analysis was carried out for these traits, for narrow and broad sense heritability and different types of gene actions was carried out according to Hayman [7], the brief discussion of the these parameters are given below.

\section{Oil content ( \%)}

Among the parents maximum oil content (49.8\%) was observed for $\mathrm{G} 2$ and minimum $(43 \%)$ was recorded for $\mathrm{G} 4$, while among $\mathrm{F}_{1}$ maximum oil content $(48.3 \%)$ was recorded for the cross $\mathrm{G} 2 \times \mathrm{G} 4$ and minimum (43.1\%) was recorded for the cross G2×G6. Rahman et al. [11], Variath et al. [12], Alemayehu and Becker [13], and Ghosh and Gulati [11, $12,13,14]$ also reported similar result of significant differences for the mentioned trait in different oil seed crops.

Table 1 shows that genotypic mean square was highly significant for oil content, so this trait was subjected to diallel analysis. As a result ' $a$ ' (6.28) and ' $b$ ' (8.56) were found highly significant for oil content (Table 2) in these genotypes of $B$. napus, indicated the major role of both additive and dominance gene action to control this trait. Rahman et al. [11] and Alemayehu and Becker [13] also reported same outcome of both additive and non-additive gene action for oil content in ethiopian mustard and toria respectively. The proportion of ' $b$ ' was found higher than ' $a$ ' showing the greater contribution of ' $b$ ' to represent variation and overall dominance component was highly significant and larger in magnitude. Rahman et al. [11] also observed similar results for seed weight plant $^{-1}$ in toria that additive effect is less important than dominance for the said trait, while Variath et al. and Ghosh and Gulati $[12,14]$ reported contrasting result of high effectiveness of additive gene action than dominance for oil content in mustard and rapeseed respectively. The $b_{1}$ component (1.89) was found non-significant. Both the $b_{2}$ (11.62) and $b_{3}$ (7.30) components of dominance were found highly significant and showed presence of specific genes effect and absence of symmetry of genes respectively. The proportion of $b_{2}$ was higher than $b_{3}$ in dominance. Non-significant values of both ' $c$ ' and ' $d$ ' values ( 0.34 and 1.31 respectively) were found so ' $a$ ' and ' $b$ ' retesting was not required. Alemayehu and Becker and Wang et al. [13, 15] observed contrasting results of significant cytoplasmic effect on oil content in mustard and rapeseed respectively.

The two tests used to prove the adequacy of additive-dominance model i.e. uniformity of $\mathrm{Wr}$ and $\mathrm{Vr}$ and analysis of regression coefficient (Table 3) following Mather and Jinks [16] revealed this model to be fully adequate for oil content.

The estimates of genetic components are given in Table 4. Both $\mathrm{D}$ (8.67) and $\mathrm{H}$ components were found significant for oil content in these genotypes, which indicated that this parameter of oil quantity was controlled by both additive and dominance genetic effects. But $\mathrm{H}$ was higher in magnitude than $D$. The value of average degree of dominance (1.344) was above unity, showing the presence of dominance for the parameter of oil content. Unequal values of $\mathrm{H}_{1}$ (15.65) and $\mathrm{H}_{2}$ (11.68) were observed, indicating the presence of unequal frequencies of both positive and negative alleles and according to Sing and Chaudhary [17] the genes will be equally distributed when the ratio of $\mathrm{H}_{2} / 4 \mathrm{H}_{1}$ results in a value equal to 0.25 and in this case for oil content it was less than 0.25 . Positive and significant $F$ value (10.72) indicated the greater proportion of dominant genes for this trait. The ratio of dominant to recessive genes represented by $\left.\left(4 \mathrm{DH}_{1}\right)^{1 / 2}+\mathrm{F} /\left(4 \mathrm{DH}_{1}\right)^{1 / 2}-\mathrm{F}\right)$ was 2.7, also resulted that less number of recessive genes are present in parents than dominant genes. The importance of recessive genes was also reported by contrasting result of Rahman et al. [11] in toria as compared to our results for the said 
trait. For the trait of oil content $\mathrm{h}^{2}$ value (0.58) was found significant showing its role in Brassica napus L. The E (environmental component) effect was also significant to indicate its role. Negative intercept of covariance $(\mathrm{Wr})$ by variance $(\mathrm{Vr})$ regression line (Figure 1) indicated overdominance gene action and in this case $\mathrm{H}_{1}$ was also greater than D which supports overdominance.

Low (0.21) narrow sense heritability and high (0.84) broad sense heritability (Table 4) for oil content was estimated, showing that greater proportion of genetic variation was of dominance nature. Wang et al. [15] observed similar result of low narrow sense heritability in $B$. napus for this trait, while contrasting result of high to medium narrow sense heritability was reported in B. juncea by Rao and Gulati [18] for this trait. Ghosh and Gulati, Aytac and Gulcan and Singh et al. $[14,19,20]$ also reported similar result of high broad sense heritability for oil content. Array points from Figure 1 showed presence of higher number of dominant genes in parent G9 for oil content, followed by G2 and G6, while in the parent G4 higher number of recessive genes or lower numbers of dominant genes were present, being farthest from origin.

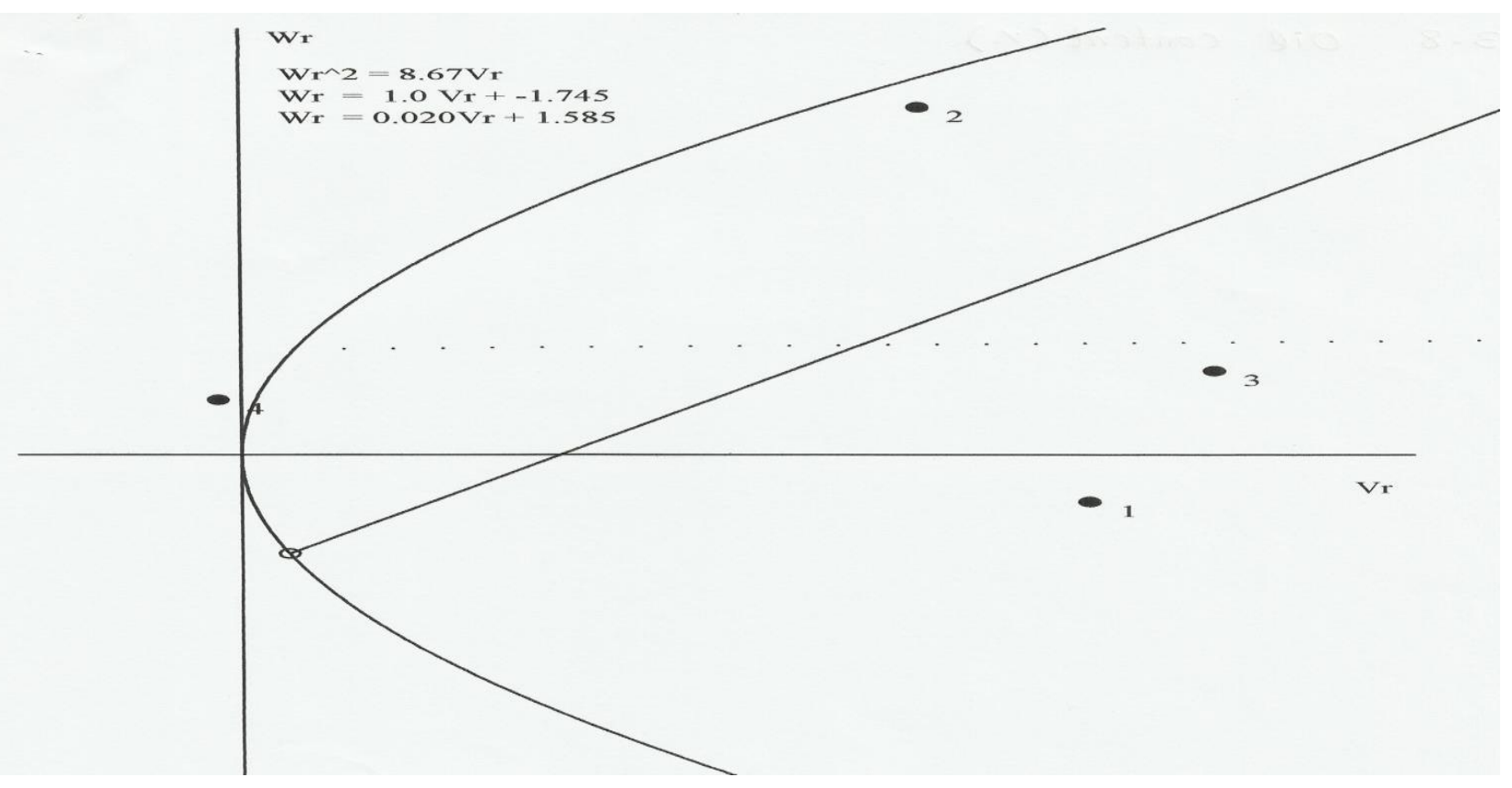

Figure 1. Wr/Vr graph for oil content (\%). 1, 2, 3 and 4 represents G1, G2, G3 and G4 parent respectively. 
Table 1. Mean squares for various parameters

\begin{tabular}{|l|l|l|l|}
\hline Character & $\begin{array}{l}\text { Replication } \\
\text { d.f=2 }\end{array}$ & $\begin{array}{l}\text { Genotype } \\
\text { d.f=15 }\end{array}$ & $\begin{array}{l}\text { Error } \\
\text { d.f=30 }\end{array}$ \\
\hline Oil content & 2.688 & $12.061^{* *}$ & 1.930 \\
\hline Protein content & 3.476 & $8.289^{* *}$ & 1.679 \\
\hline Glucosinolate content & 27.713 & $423.942^{* *}$ & 46.948 \\
\hline Erucic acid & 76.079 & $231.014^{*}$ & 10.166 \\
\hline Linolenic acid & 0.810 & $1.580^{* *}$ & 0.458 \\
\hline
\end{tabular}

Table 2. Analyses of variance for various parameters in a $4 \times 4$ diallel cross of Brassica napus $\mathbf{L}$

\begin{tabular}{|l|l|l|l|l|l|l|}
\hline $\begin{array}{l}\text { Source of } \\
\text { variation }\end{array}$ & df & $\begin{array}{l}\text { Oil } \\
\text { content }\end{array}$ & $\begin{array}{l}\text { Protein } \\
\text { content }\end{array}$ & $\begin{array}{l}\text { Glucosinolate } \\
\text { content }\end{array}$ & Erucic acid & $\begin{array}{l}\text { Linolenic } \\
\text { acid }\end{array}$ \\
\hline $\mathrm{A}$ & 3 & $6.25^{* *}$ & $7.60^{* *}$ & $29.24^{* *}$ & $69.96^{* *}$ & $1.98^{\mathrm{ns}}$ \\
\hline $\mathrm{B}$ & 6 & $8.56^{* *}$ & $7.15^{* *}$ & $5.43^{* *}$ & $19.92^{* *}$ & $5.26^{* *}$ \\
\hline $\mathrm{B}_{1}$ & 1 & $1.89^{\mathrm{ns}}$ & $5.10^{*}$ & $20.29^{* *}$ & $75.65^{* *}$ & $6.62^{*}$ \\
\hline $\mathrm{B}_{2}$ & 3 & $11.62^{* *}$ & $5.40^{* *}$ & $4.05^{*}$ & $14.26^{* *}$ & $6.57^{* *}$ \\
\hline $\mathrm{B}_{3}$ & 2 & $7.30^{* *}$ & $10.81^{* *}$ & $0.07^{\mathrm{ns}}$ & $0.54^{\mathrm{ns}}$ & $2.62^{\mathrm{ns}}$ \\
\hline $\mathrm{C}$ & 3 & $0.34^{\mathrm{ns}}$ & $0.39^{\mathrm{ns}}$ & $1.51^{\mathrm{ns}}$ & $1.40^{\mathrm{ns}}$ & $0.60^{\mathrm{ns}}$ \\
\hline $\mathrm{D}$ & 3 & $1.31^{\mathrm{ns}}$ & $0.30^{\mathrm{ns}}$ & $1.08^{\mathrm{ns}}$ & $0.71^{\mathrm{ns}}$ & $0.14^{\mathrm{ns}}$ \\
\hline
\end{tabular}

Table 3. Tests for adequacy of additive-dominance model for $4 \times 4$ diallel crosses in $B$. napus $L$

\begin{tabular}{|l|ll|l|l|}
\hline & \multicolumn{2}{|l|}{$\begin{array}{l}\text { Tests for adequacy of additive- } \\
\text { dominance }\end{array}$} & \\
\hline Parameters & $\begin{array}{l}\text { Regression } \\
\text { analysis } \\
\text { b=0 } \quad \text { b=1 }\end{array}$ & $\begin{array}{l}\text { uniformity of Wr } \\
\text { and Vr }\end{array}$ & Remarks \\
\hline Oil content & $*$ & NS & NS & $\begin{array}{l}\text { Additive-dominance model } \\
\text { was fully adequate. }\end{array}$ \\
\hline Protein content & $*$ & NS & NS & $\begin{array}{l}\text { Additive-dominance model } \\
\text { was fully adequate. }\end{array}$ \\
\hline $\begin{array}{l}\text { Glucosinolate } \\
\text { content }\end{array}$ & $*$ & NS & $*$ & $\begin{array}{l}\text { Additive-dominance model } \\
\text { was partially adequate. }\end{array}$ \\
\hline Erucic acid & NS & NS & NS & $\begin{array}{l}\text { Additive-dominance model } \\
\text { was partially adequate. }\end{array}$ \\
\hline Linolenic acid & NS & NS & NS & $\begin{array}{l}\text { Additive-dominance model } \\
\text { was partially adequate. }\end{array}$ \\
\hline
\end{tabular}


Table 4. Estimates of genetic components of various parameters in a $4 \times 4$ diallel cross of Brassica napus L.

\begin{tabular}{|l|l|l|l|l|l|}
\hline $\begin{array}{l}\text { Source of } \\
\text { variation }\end{array}$ & Oil content & $\begin{array}{l}\text { Protein } \\
\text { content }\end{array}$ & $\begin{array}{l}\text { Glucosinolate } \\
\text { content }\end{array}$ & Erucic acid & $\begin{array}{l}\text { Linolenic } \\
\text { acid }\end{array}$ \\
\hline $\mathrm{D}$ & $8.67^{*} \pm 3031$ & $3.19^{\mathrm{ns}} \pm 1.17$ & $129.07^{*} \pm 55.26$ & $235.59^{*} \pm 33.31$ & $0.13^{\mathrm{ns}} \pm 0.35$ \\
\hline $\mathrm{H}_{1}$ & $15.65^{*} \pm 5.21$ & $8.53^{*} \pm 3.09$ & $169.31^{*} \pm 78.42$ & $151.79^{*} \pm 29.82$ & $2.28^{*} \pm 1.10$ \\
\hline $\mathrm{H}_{2}$ & $11.68^{*} \pm 3.84$ & $7.31^{*} \pm 2.57$ & $146.49^{*} \pm 64.68$ & $129.58^{*} \pm 24.84$ & $1.74^{*} \pm 0.83$ \\
\hline $\mathrm{F}$ & $10.72^{\mathrm{ns}} \pm 4.11$ & $2.54^{\mathrm{ns}} \pm 1.99$ & $-76.26^{\mathrm{ns}} \pm 43.81$ & $140.53^{*} \pm 31.20$ & $0.59^{\mathrm{ns}} \pm 0.63$ \\
\hline $\mathrm{h}^{2}$ & $0.58 \pm 1.87$ & $1.86^{\mathrm{ns}} \pm 2.10$ & $237.36^{\mathrm{ns}} \pm 110.83$ & $191.43^{*} \pm 44.42$ & $0.87^{\mathrm{ns}} \pm 0.82$ \\
\hline $\mathrm{E}$ & $0.77^{*} \pm 0.20$ & $0.59^{*} \pm 0.15$ & $16.30^{*} \pm 4.16$ & $3.41^{*} \pm 0.86$ & $0.20^{*} \pm 0.05$ \\
\hline$(\mathrm{H} 1 / \mathrm{D}) 1 / 2$ & 1.344 & 1.636 & 1.145 & 0.803 & 4.156 \\
\hline $\mathrm{H} 2 / 4 \mathrm{H} 1$ & 0.18 & 0.21 & 0.22 & 0.21 & 0.19 \\
\hline $\begin{array}{l}(4 \mathrm{DH} 1) 1 / 2+\mathrm{F} \\
(4 \mathrm{DH} 1) 1 / 2-\mathrm{F}\end{array}$ & 2.71 & 1.64 & 1.59 & 2.18 & 3.40 \\
\hline Heritability(ns) & 0.206 & 0.279 & 0.683 & 0.621 & 0.054 \\
\hline Heritability(bs) & 0.835 & 0.824 & 0.902 & 0.964 & 0.701 \\
\hline
\end{tabular}

ns shows non-significant.

* Value is significant, when after division by its standard error, exceeds 1.96.

\section{Protein content $(\%)$}

Among the parents maximum protein content $(22.9 \%)$ was observed for G9 and minimum content $(20.9 \%)$ was recorded for G2, while among $F_{1}$ maximum protein content $(26.7 \%)$ was recorded for the cross G2×G6 and minimum content $(21.9 \%)$ was recorded for the crosses G9 $\times \mathrm{G} 6$ and G6 $\times$ G9. Variath et al. and Alemayehu and Becker [12, 13] also reported similar result of significant differences for the mentioned trait in ethiopian mustard and $B$. napus respectively.

Table 1 shows that genotypic mean square was highly significant for protein content, so this trait was subjected to diallel analysis. In the result ' $a$ ' (7.60) and ' $b$ ' (7.15) were observed to be highly significant for protein content (Table 2), showing the importance of both non-additive and additive gene action to control this trait in these studied genotypes of $B$. napus. Alemayehu and Becker [13] also reported the importance of both additive and non-additive gene action for protein content in mustard. The proportion of ' $b$ ' was lower than ' $a$ ' showing the higher proportion of ' $a$ ' to represent genetic variation for protein content and overall additive component was larger and highly significant. Variath et al. [12] also reported higher and significant value of ' $a$ ' component for the protein content in $B$. napus. Moreover they also stated that dominance component is less important than additive component for the stated trait. The $b_{1}$ component (5.10) was found significant and was responsible for a lower proportion of dominance than $b_{2}$ (5.40) and $b_{3}$ (10.81). Both the $b_{2}$ and $b_{3}$ components of dominance were found highly significant and represented both the absence of symmetry of genes and presence of specific genes effect. Non-significant values of both ' $c$ ' and ' $d$ ' (0.39 and 0.30 respectively) were found, so retesting of a and $b$ was not required. Variath et al. [12] reported significant effect of cytoplasm for protein content in B. napus.

The two tests used to prove the adequacy of additive-dominance model i.e. uniformity of $\mathrm{Wr}$ and $\mathrm{Vr}$ and analysis of regression coefficient (Table 3) following Mather and Jinks [16] revealed this model to be fully adequate for protein content. 
The estimates of genetic components for protein content are given in Table 4. Nonsignificant value of D (3.19) and high and significant value of $\mathrm{H}$ component were found for protein content, which showed higher role of dominance genetic effects for protein content in these genotypes. The average degree of dominance value was 1.636, greater than unity and indicated dominance gene action for protein content. Unequal values of $\mathrm{H}_{1}$ (8.53) and $\mathrm{H}_{2}$ (7.31) were observed indicating unequal frequencies the presence of both dominant and recessive alleles. Following Sing and Chaudhary [17] when the ratio of $\mathrm{H}_{2} / 4 \mathrm{H}_{1}$ is 0.25 , genes will be equally distributed. The value of $\mathrm{F}$ was positive and non-significant. Dominant to recessive genes ratio $\left(4 \mathrm{DH}_{1}\right)^{1 / 2}$ $\left.+\mathrm{F} /\left(4 \mathrm{DH}_{1}\right)^{1 / 2}-\mathrm{F}\right)$ was 1.64 , which showed that less number of recessive genes are present in parents than dominant genes. The $\mathrm{h}^{2}$ value was non-significant. The role of $\mathrm{E}$ (environmental component) was also significant, playing its role in the expression of the said trait. $\mathrm{H}_{1}$ was also greater than $\mathrm{D}$ which supports overdominance, also shown by negative intercept of covariance (Wr) by variance $(\mathrm{Vr})$ regression line (Figure 2).

High (0.82) broad sense heritability and Low (0.28) narrow sense heritability (Table 4) was estimated for protein content, indicating the higher value of genetic variation for the said trait was of dominance nature. $\mathrm{Wu}$ et al. [21] reported contrasting result of medium narrow sense heritability for protein content in rapeseed, whereas Aytac and Gulcan and Singh et al. [19, 20] also reported high broad sense heritability for the mentioned trait.

From Figure 2 array points showed that parent G9 is having higher number of dominant genes for protein content, following G4 and G6, while in the parent G2 lower number of dominant genes or higher number of recessive genes were present, being farthest from origin.

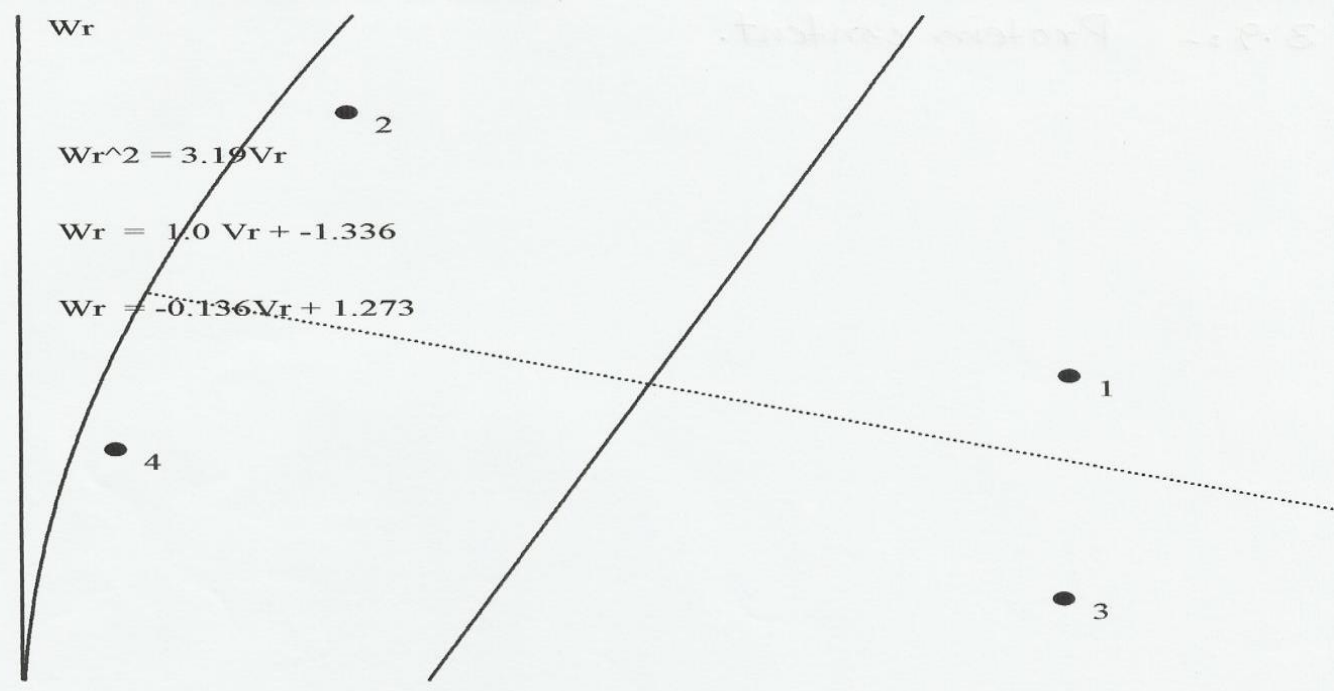

Figure 2. Wr/Vr graph for protein content (\%). 1, 2, 3 and 4 represents G1, G2, G3 and G4 parent respectively. 


\section{Glucosinolate content $\left(\boldsymbol{\mu m o l} \mathbf{g}^{-1}\right)$}

Among the parents maximum glucosinolate content $\left(88.6 \mu \mathrm{mol} \mathrm{g}^{-1}\right)$ was observed for G6 and minimum content $\left(63.0 \mu \mathrm{mol} \mathrm{g}^{-1}\right)$ was recorded for $\mathrm{G} 9$, while among $\mathrm{F}_{1}$ maximum glucosinolate content $\left(98.2 \mu \mathrm{mol} \mathrm{g} \mathrm{g}^{-1}\right)$ was recorded for the cross $\mathrm{G} 6 \times \mathrm{G} 2$ and minimum content $\left(72.7 \mu \mathrm{mol} \mathrm{g}^{-1}\right)$ was recorded for the cross $\mathrm{G} 9 \times \mathrm{G} 2$. Alemayehu and Becker and Rameah et al. [13, 22] also reported similar result of significant differences for the mentioned trait in B. napus and ethiopian mustard respectively.

Table 1 shows that genotypic mean square was highly significant for glucosinolate content, so this trait was subjected to diallel analysis. As a result 'a' (29.24) and 'b' (5.43) values were found highly significant for glucosinolate content (Table 2) showing the importance of both types of gene action to control glucosinolate content in these genotypes of $B$. napus. Alemayehu and Becker and Rameah et al. [13, 22] also reported similar result in $B$. napus and Ethiopian mustard respectively. The proportion of ' $b$ ' was lower than ' $a$ ' indicating the higher proportion of ' $a$ ' to represent variation and overall additive component was larger and highly significant. Alemayehu and Becker [13] also observed partially similar result in Ethiopian mustard that additive component of variance was twice as compared to dominance variance. The $b_{1}$ component of dominance (20.29) was found highly significant and greater than $b_{2}(4.05)$ and $b_{3}(0.07)$. The significant $b_{2}$ component of dominance represented the absence of symmetry of genes. The $b_{3}$ component was found nonsignificant and indicated absence of specific gene effects. Non-significant values of both the 'c' (0.51) and 'd' (1.08) were found, so the retesting of $a$ and $b$ was not necessary. Alemayehu and Becker [13] reported contrasting result in Ethiopian mustard that cytoplasm has a meager role to control glucosinolate level along with nuclear genes, while significant contrasting result of maternal effect on this trait in B. napus was reported by Rameah et al. [22].

The two tests used to prove the adequacy of additive-dominance model i.e. uniformity of $\mathrm{Wr}$ and $\mathrm{Vr}$ and analysis of regression coefficient (Table 3) following Mather and Jinks [16] revealed this model to be partially adequate for glucosinolate content.

Table 4 shows the estimates of genetic components for glucosinolate content. Significant values of both D (129.07) and H components were found, showing that the parameter of glucosinolate content in these genotypes was under the control of both additive and non-additive genetic affect. But the magnitude of $\mathrm{H}$ was larger than $\mathrm{D}$. Average degree of dominance value (1.145) was found greater than one which indicated the presence of dominance for the mentioned trait. Values of $\mathrm{H}_{1}$ (169.31) and $\mathrm{H}_{2}$ (146.49) were not equal. Inequality of $\mathrm{H}_{1}$ and $\mathrm{H}_{2}$ showed the presence of both dominant and recessive alleles with unequal frequencies and according to Sing and Chaudhary [17] genes will be equally distributed when the ratio of $\mathrm{H}_{2} / 4 \mathrm{H}_{1}$ is 0.25 and in this case it was less than 0.25. F value was found non-significant and negative, indicating higher frequency of recessive genes and dominant to recessive allele's ratio (0.59) also supported it, as it was less than one. The $\mathrm{h}^{2}$ value was significant. The environmental component $\mathrm{E}$ effect was also found significant to indicate its role for this trait. Negative intercept of covariance (Wr) by variance (Vr) regression line (Figure 3) indicated overdominance gene action and in this case $\mathrm{H}_{1}$ (169.31)was greater than D (129.07) which also supports it. Alemayehu and Becker [13] reported contrasting result in ethiopian mustard that partial dominance mainly controls glucosinolate content trait, although up to some extent overdominance also take role. 
High narrow (0.68) and broad (0.90) sense heritabilities (Table 4) were estimated for glucosinolate content, indicating the greater proportion of genetic variation for this parameter was of additive nature. Zang and Zhou [23] reported partially similar result of medium broad sense heritability for this trait in B. oleracea, whereas Rameah et al. [22] reported similar result of high narrow sense heritability in rapeseed for the mentioned trait. Moreover they reported that due to high narrow sense heritability additive gene action is very important for the expression of this trait. From Figure 3 array points showed that parent G6 possess higher number of dominant genes for glucosinolate content being nearest to origin, following G9 and G2, while the parent G4 possess higher number of recessive genes or lower number of dominant genes, being farthest from origin.

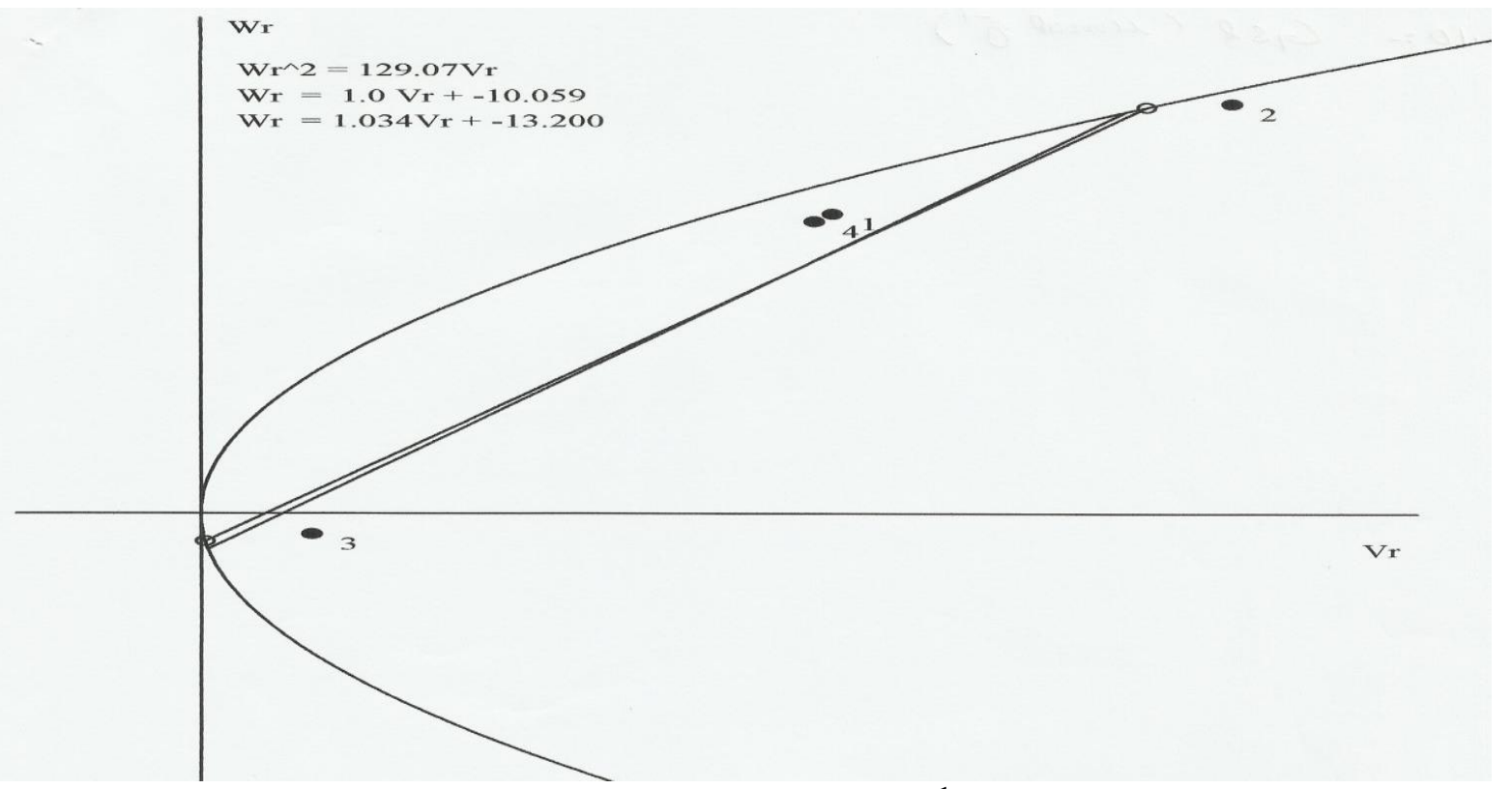

Figure 3. Wr/Vr graph for glucosinolate content ( $\left.\mu \mathrm{mol} \mathrm{g}^{-1}\right), 1,2,3$ and 4 represents G1, G2, G3 and G4 parent respectively.

\section{Erucic acid content (\%)}

Among the parents maximum erucic acid content $(49.6 \%)$ was observed for G6 and minimum content $(15.6 \%)$ was recorded for G9, while among $F_{1}$ maximum erucic acid content $(53.6 \%)$ was recorded for the cross G6 $\times$ G4 and minimum content $(41.9 \%)$ was recorded for the cross $\mathrm{G} 9 \times \mathrm{G} 2$. Rio-M et al. and Qi et al. [24, 25] also reported similar result of significant differences for the mentioned trait in B. napus and B. carinata.

Table 1 shows that genotypic mean square was highly significant for erucic acid content, so this trait was subjected to diallel analysis. In the result ' $a$ ' (69.96) and ' $b$ '
(19.92) were found highly significant for erucic acid content (Table 2) indicating the importance of both additive and nonadditive gene action to control this trait in these studied genotypes of B. napus. Ecker and Yaniv [26] also reported similar result of the involvement of both additive and nonadditive gene action manipulates the erucic acid content in Sinapis alba L. The proportion of ' $b$ was much lower than ' $a$ ' showing the higher proportion of ' $a$ ' to represent variation and overall additive component was highly significant and larger in magnitude. Rio-M et al. [24] reported contrasting result effectiveness of only 
additive gene action for the expression of the mentioned trait in $B$. carinata, whereas Ecker and Yaniv [26] reported the importance of additive genetic inheritance along with partial dominance for the mentioned trait in Sinapis alba L. Highly significant values of both $b_{1}$ and $b_{2}$ components were found, whereas the $b_{3}$ component of dominance was found nonsignificant. The proportion of $b_{1}$ dominance (75.65) was greater than both $b_{2}(14.26)$ and $b_{3}(0.54)$. The $b_{3}$ component proportion was lower than $b_{2}$ and $b_{1}$. Non-significant values of both ' $c$ ' and ' $d$ ' values (1.40 and 0.71 respectively) were found, so retesting of ' $a$ ' and ' $b$ ' was not required.

The two tests used to prove the adequacy of additive-dominance model i.e. uniformity of $\mathrm{Wr}$ and $\mathrm{Vr}$ and analysis of regression coefficient (Table 3) following Mather and Jinks [16] revealed this model to be partially adequate for erucic acid content.

Table 4 shows the estimates of genetic components for erucic acid content. D (235.59) and $\mathrm{H}$ components were found significant, indicating that the studied trait of erucic acid content in these genotypes was under the control of both these type of gene effects, but the magnitude of $\mathrm{D}$ was higher than $\mathrm{H}$. Values of $\mathrm{H}_{1}(151.79)$ and $\mathrm{H}_{2}$ (129.58) were unequal. Unequal frequencies of both dominant and recessive alleles was shown by inequality of $\mathrm{H}_{1}$ and $\mathrm{H}_{2}$ and according to Sing and Chaudhary [17] when ratio of $\mathrm{H}_{2} / 4 \mathrm{H}_{1}$ is 0.25 , genes will be equally distributed and in this case it was less than 0.25 . The value of $F$ was positive and significant, showing higher frequency of dominant genes and the ratio of dominant to recessive alleles (2.18) also supported it, which was greater than one. The $h^{2}$ value was found significant. The environmental component $\mathrm{E}$ effect was also significant to indicate its role for this trait. Positive intercept of covariance (Wr) by variance $(\mathrm{Vr})$ regression line (Figure 4) indicated partial dominance and in this case $\mathrm{H}_{1}$ was also lower than D, which supports partial dominance. Ecker and Yaniv [26] reported similar result of the importance of partial dominance for the mentioned trait in Sinapis alba L. High narrow (0.62) and broad (0.96) sense heritabilities (Table 4) were estimated for erucic acid content, showing genetic variation in higher proportion for this parameter was of additive nature. Similar result of high broad sense heritability was reported by Khan et al. [27] for erucic acid content in brassica, whereas Zhang and Zhou [23] reported partially similar result of medium broad sense heritability in $B$. oleracea L. for this trait. Ecker and Yaniv [26] reported similar result for both high broad and narrow sense heritability in Sinapis alba L. for the erucic acid content. From Figure 4 array points showed that parent G6 possess higher number of dominant genes for erucic acid content being nearest to origin, following G2 and G4, while the parent G9 possesses higher number of recessive genes or lower number of dominant genes, being farthest from origin. 


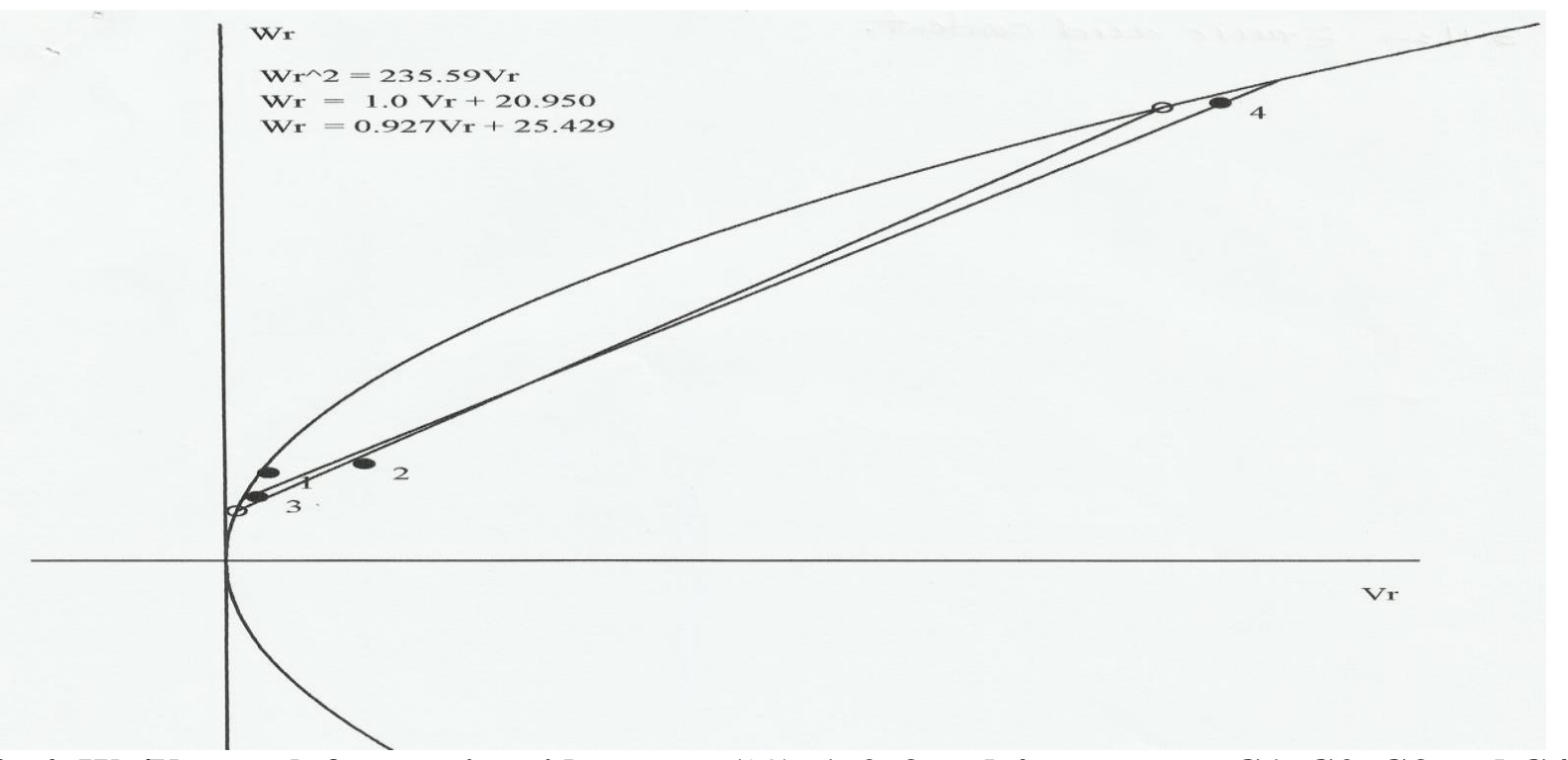

Fig 4. Wr/Vr graph for erucic acid content (\%). 1, 2, 3 and 4 represents G1, G2, G3 and G4 parent respectively.

\section{Linolenic acid content $(\%)$}

Among the parents maximum linolenic acid content $(8.6 \%)$ was observed for parent G9 and minimum content $(8.4 \%)$ was recorded for G6 and G9, while among $F_{1}$ maximum linolenic acid content (10\%) was recorded for the cross $\mathrm{G} 4 \mathrm{xG} 9$ and minimum content $(7.6 \%)$ was recorded for the cross $\mathrm{G} 2 \mathrm{xG} 9$. Zhang et al. and Rajcan et al. [28, 29] also observed significant differences for the mentioned trait in B. napus L.

Table 1 shows that genotypic mean square was highly significant for protein content, so this trait was subjected to diallel analysis. In the result 'a' (1.98) and 'b' (5.26) were found non-significant and highly significant respectively for protein content (Table 2), which indicated the dominance gene action importance to control linolenic acid content in these genotypes of $B$. napus. Gesteira et al. [30] also reported similar result in soybean, that both these type of gene actions are important for the expression of the mentioned trait. Proportion of ' $b$ ' (5.26) was higher than ' $a$ ' (1.98), indicating the greater role of ' $b$ ' to represent genetic variation for the said trait, so overall non-additive component was highly significant and larger than additive. Gesteira et al. [30] reported higher and significant value of additive gene action for this trait in soybean as compared to dominance gene action. The $\mathrm{b}_{1}$ component (6.62) was found to be responsible for a higher proportion of dominance than other two components $\left(b_{2}=6.57\right.$ and $\left.b_{3}=2.62\right)$. The $\mathrm{b}_{2}$ component of dominance was observed to be highly significant representing the absence of symmetry of genes whereas, $b_{3}$ components of dominance was found nonsignificant indicating absence of specific genes effect. Non-significant values for both 'c' and 'd' ( 0.60 and 0.14 respectively) were found, that's why retesting of a and $b$ was not required. However, according to Zhang et al. and Rajcan et al. [28, 29] cytoplasmic effect has importance for linolenic acid inheritance.

The two tests used to prove the adequacy of additive-dominance model i.e. uniformity of $\mathrm{Wr}$ and $\mathrm{Vr}$ and analysis of regression coefficient (Table 3) following Mather and Jinks [16] revealed this model to be partially adequate for linolenic acid content.

Table 4 shows the estimates of genetic components for linolenic acid content. Nonsignificant value of D (0.13) and high and 
significant value of $\mathrm{H}$ component were found for linolenic acid content in these genotypes showing the high control of dominance gene affects for linolenic acid content. Average degree of dominance value (4.156) was observed higher than one, showing the presence of dominance for the studied parameter. Unequal values of $\mathrm{H}_{1}$ (2.28) and $\mathrm{H}_{2}$ (1.74) were found. Inequality of $\mathrm{H}_{1}$ and $\mathrm{H}_{2}$ indicated the presence unequal frequencies of dominant and recessive alleles. Singh and Chaudhary [17] recommended when the ratio of $\mathrm{H}_{2} / 4 \mathrm{H}_{1}$ is 0.25 , genes will be equally distributed and in this case it was less than 0.25 . The value of F (0.59) was positive and non-significant. Dominant to recessive genes ratio $\left(4 \mathrm{DH}_{1}\right)^{1 / 2}$ $\left.+\mathrm{F} /\left(4 \mathrm{DH}_{1}\right)^{1 / 2}-\mathrm{F}\right)$ was 3.40 showing that in parents less number of recessive genes are present as compared to dominant genes. $\mathrm{h}^{2}$ value (0.87) was non-significant. The effect of environmental component $(\mathrm{E}=0.20)$ was significant to indicate its role in the expression of the said trait. Zhang et al. [28] also reported similar result of significant effect of environment on the expression of linolenic acid parameter. The negative intercept of covariance (Wr) by variance $(\mathrm{Vr})$ regression line (Figure 5) indicated overdominance gene action and in this case $\mathrm{H}_{1}$ was also greater than $\mathrm{D}$, which also supports overdominance.

High broad sense (0.70) heritability and low narrow sense (0.054) heritability was estimated for linolenic acid content (Table 4), which indicated the greater proportion of dominance genetic variation for the said trait. Ecker and Yaniv [26] reported partially similar result for both high broad and narrow sense heritability in Sinapis alba L. for the erucic acid content. Zang et al. [28] reported medium broad sense heritability for this trait, which is partially similar to our result. From Figure 5 array points showed that parent $\mathrm{G} 2$ possess greater number of dominant genes for linolenic acid content, followed G6 and G9, while in the parent G4 higher number of recessive genes or lower number of dominant genes were present, being farthest from origin.

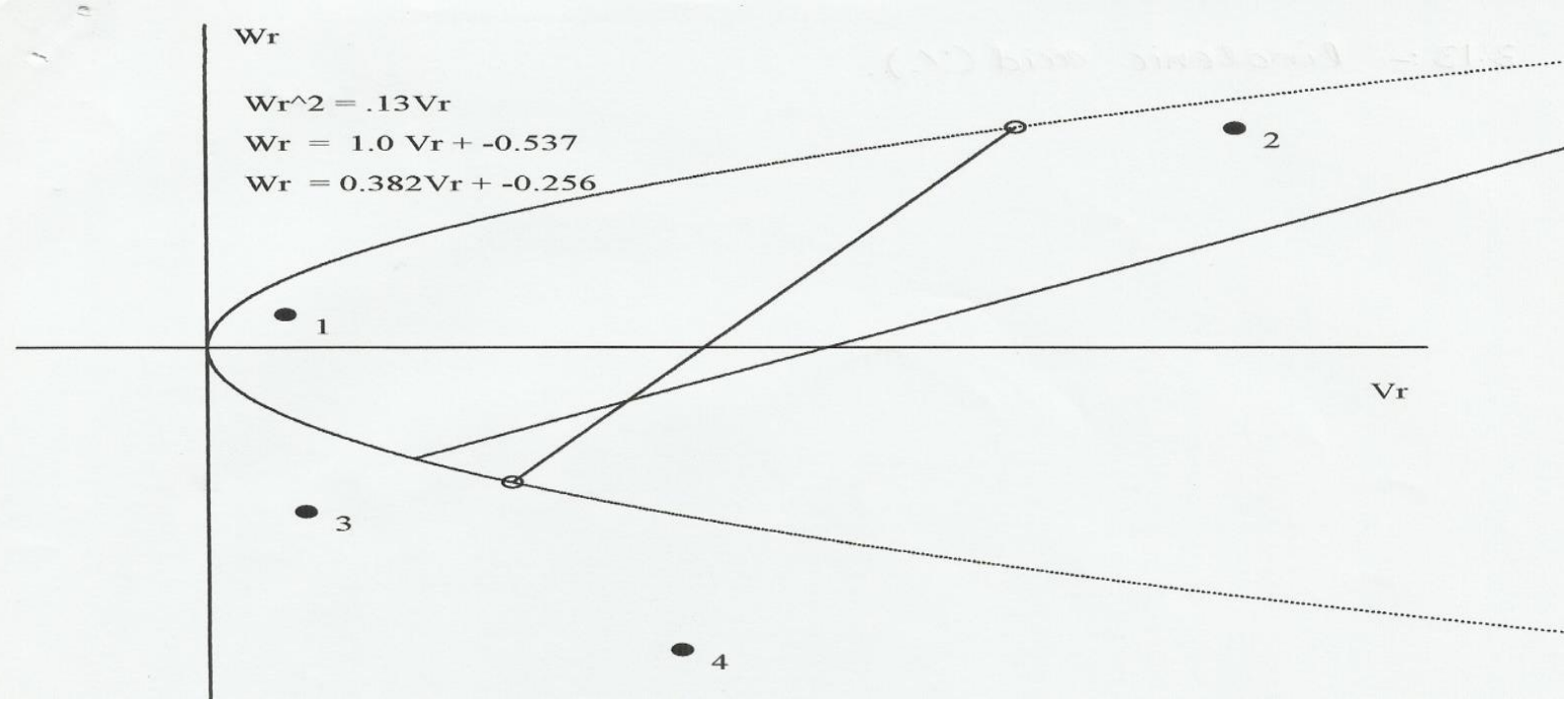

Figure 5. Wr/Vr graph for linolenic acid content (\%). 1, 2, 3 and 4 represents G1, G2, G3 and G4 parent respectively.

\section{Conclusion}

Among parental genotypes, G9 excelled for seed quality traits followed by G1, whereas among the hybrids $\left(\mathrm{F}_{1}\right)$, performance of $\mathrm{G} 2 \times \mathrm{G} 6$, G4×G6 and $\mathrm{G} 4 \times \mathrm{G} 9$ were superior then rest of the crosses. Both the additive (a) 
and non-additive (b) components were significant for all of the studied parameters in the result of diallel analysis, except linolenic acid for which additive component was non-significant. Both the ' $c$ ' and ' $d$ ' components values which shows maternal effect and reciprocal effect respectively, were non-significant. From graphical analysis, all the traits showed overdominance type of gene action, except erucic acid for which partial dominance was observed. High broad and narrow sense heritabilities were estimated for glucosinolate and erucic acid content, which shows the presence of more control of additive gene action whereas, high broad sense and low narrow sense heritability was estimated for the rest of the traits, showing the presence of more control of dominance gene action for these traits. The information obtained from the present study could be used to develop desirable line, especially selection for traits such as high oil and protein content in later generations in any rapeseed breeding program.

\section{Authors' contributions}

Conceived and designed the experiments: $M$ Ali, R Din \& IH Khalil, Performed the experiments: M Ali \& R Din, Analyzed the data: IA Khalil, AU Haq \& $\mathrm{R}$ Khan, Contributed reagents/ materials/ analysis tools: Ghulamullah \& MU Rehman, Wrote the paper: M Ali \& SKhan.

\section{References}

1. Canadian encyclopedia. http://www.thecanadianencyclopedia.ca/e $\mathrm{n} /$ article/oilseed-crops.

2. Wang HZ (2005). The potential problems and strategy for the development of biodiesel using oilseed rape. Chin. J. Oil Crop Sci 27:74-76.

3. Friedt WR, Snowdon F, Ordon \& Ahlemeyer J (2007). Plant Breeding: assessment of Genetic Diversity in Crop Plants and its Exploitation in Breeding. Progress in Botany 168: 152-178.
4. Marjanovic JA (2005). Genetic divergence and variability of rapeseed (Brassica napus L.). PhD thesis, Faculty of Agriculture, University of Novi Sad.

5. Wang HZ (2004). Strategy for rapeseed genetic improvement in China in the coming fifteen years. Chin. J. Oil Crop Sci 26:98-101.

6. Velasco L \& Becker HC (1998). Estimating the fatty acid composition of the oil in intact-seed rapeseed by near-infrared reflectance spectroscopy. Euphytica 101: 221-230.

7. Hayman BI (1954a). The analysis of diallel tables. Biometrics 10: 235-244.

8. Hayman BI (1954b). The theory and analysis of diallel crosses. Genetics 39: 789-809.

9. Mather K \& Jinks JL (1977). Introduction to Biometrical Genetics. Champman and Hall Ltd. London. $1^{\text {st }}$ ed. pp 73-80.

10. Steel RGD \& Torrie JH (1980). Principles and procedure of statistics. MmGraw-Hill Book co., Inc., New York. USA.

11. Rahman MM, Chowdhury MAZ, Hossain MG, Amin MN, Muktadir MA \& Rashid MH (2011). Gene action for seed yield and yield contributing characters in turnip rape (Brassica rapa L.). J. Expt. Biosci 2: 67-76.

12. Variath M, Wu TAJG, Li AYX, Chen AGL \& Shi H (2009). Genetic analysis for oil and protein contents of rapeseed (Brassica napus L.) at different developmental times. Euphytica 166: 145-153.

13. Alemayehu N \& Becker H (2005). Quantitative genetic analysis of total glucosinolate, oil and protein content in Ethiopian mustard (Brassica carinata A. Braun). Ethiopian J. Sci 28(2): 141-150.

14. Ghosh SK \& Gulati S (2001). Genetic variability and association of yield components in Indian mustard (Brassica juncea L.). Crop Res. 2(3): 345-349.

15. Wang X, Guihua L, Qing Y, Wei H, Jing L \& Hanzhong W (2009). Genetic analysis 
on oil content in rapeseed (Brassica napus L). Euphytica Int. J. Plant Breed. Abstract \# 10.1007/s10681-009-0062. Published online, 27 Oct. 2009.

16. Mather K \& Jinks JL (1982). Introduction to Biometrical Genetics. Champman and Hall Ltd. London.

17. Singh RK \& Chaudhry BD (1985). Biometrical methods in Quantitative Genetic analysis. Kalyani Pub., Ludhiana, New Delhi, Revised Ed. pp.102-118.

18. Rao NV \& Gulati SC (2001). Combining ability of $F_{1}$ and $F_{2}$ diallels of Indian mustard (Brassica juncea L. Czem and Coss). Crop Res 21: 72-76.

19. Aytac Z \& Kinaci G (2009). Genetic variability and association studies of some quantitative characters in winter rapeseed (Brassica napus L). African J. Biotech 8(15): 3547-3554.

20. Singh M, Swarnker GB, Prasad L \& Rai G (2002). Genetic variability, heritability and genetic advance for quality traits in Indian mustard (Brassica juncea L.). Plant Arch 2(1): 27-31.

21. Wu JG, Shi CH \& Zhang HZ (2004).

Genetic analysis of embryo, cytoplasmic and maternal effects and their environment interactions for protein content in Brassica napus L. Aus. J. Agric. Resch 56(1): 69-73.

22. Rameah V, Rezai A \& Saeidi G (2003).

Estimation of Genetic Parameters for Yield, Yield Components and Glucosinolate in Rapeseed (Brassica napus L). J. Agric. Sci. Tech 5: 143-151.

23. Zhang G \&. Zhou W (2006). Genetic analyses of agronomic and seed quality traits of synthetic oilseed Brassica napus produced from interspecific hybridization of B. campestris and B. oleracea. $J$. Genetics 85(1): 45-51.

24. Rio D, Haro D \& Martínez JMF (2003). Transgressive segregation of erucic acid content in Brassica carinata A. Braun. Theor. Appl. Genet 107(4): 643-651.

25. Qi CK, Gai JY \& Zhang YM (2001). Major gene plus polygene inheritance of erucic acid content in Brassica napus L. Acta Genet. Sin 28: 182-187.

26. Ecker R \& Yaniv Z (1993). Genetic control of fatty acid composition in seed oil of Sinapis alba L. Euphytica 69(1): 45-49.

27. Khan S, Farhatullah, Khalil IH, Khan MY \& Ali N (2008). Genetic variability, heritability and correlation for some quality traits in $\mathrm{F}_{3: 4}$ Brassica populations. Sarhad J. Agric 24(2): 223-231.

28. Zhang H, Chunhai S, Jianguo W, Yuling R, Changtao L, Dongqing Z, \& Yaofeng Z (2004). Analysis of genetic effects and heritabilities for linoleic and $\alpha$-linolenic acid content of Brassica napus L. across Chinese environments. Euro. J. Lipid Sci. Tech 106(8): 518-523.

29. Rajcan KJ, Kasha, Kott LS \& Beversdorf WD (2002). Evaluation of cytoplasmic effects on agronomic and seed quality traits in two doubled haploid populations of Brassica napus L. Euphytica 123: 401-409.

30. Gesteira ADS, Schuster I, Jose IC, Piovesan ND, Viana JMS, Barros EGD \& Moreira MA (2003). Biometrical analyses of linolenic acid content of soybean seeds. Genet. Mol. Bio. 26(1): 65-68. 